\title{
Analisis pelaksanaan mata kuliah pengenalan lapangan persekolahan (plp) secara daring berdasarkan experiential learning theory
}

Benedecta Indah Nugraheni

Program Pascasarjana Universitas Negeri Yogyakarta, Indonesia

e-mail: benedectaindah.2020@student.uny.ac.id

\begin{abstract}
Abstrak
PLP merupakan mata kuliah praktik lapangan untuk memberi pengalaman langsung secara komprehensif kepada mahasiswa Fakultas Keguruan dan Ilmu Pendidikan (FKIP) mengenai dunia persekolahan dan untuk mengembangkan berbagai kompetensi yang dimiliki seorang guru profesional. Dengan adanya pandemi covid-19, PLP dilaksanakan secara daring, sehingga mahasiswa tidak dapat memperoleh pengalaman secara langsung di sekolah tempat pelaksanaan PLP. Praktik ini menjadi kurang ideal untuk mata kuliah PLP. Penelitian ini bertujuan menganalisis hasil refleksi pengalaman mahasiswa peserta PLP secara daring untuk mengetahui penguasaan capaian pembelajaran yang telah ditetapkan, pengalaman-pengalaman positif yang diperoleh dan kendala yang dihadapi mahasiswa, sikap atau nilai-nilai yang berkembang dalam diri mahasiswa, serta pengalaman inspiratif dan niat-niat yang dibangun untuk pengembangan diri yang muncul berdasarkan hasil refleksi. Penelitian ini merupakan penelitian kualitatif. Hasil penelitian menunjukkan bahwa mahasiswa dapat menguasai capaian pembelajaran dengan baik dan sangat baik, mahasiswa memperoleh berbagai pengalaman positif dan pengalaman mengatasi kendala yang muncul akibat pandemi, ada sikap atau nilai-nilai baik yang berkembang dalam diri mahasiswa, mahasiswa memperoleh pengalaman
\end{abstract}


inspiratif, dan muncul niat-niat dari mahasiswa untuk pengembangan diri. Dengan demikian, siklus belajar dalam experiential learning theory dialami oleh mahasiswa peserta PLP daring.

Kata kunci: Pengenalan Lapangan Persekolahan, daring, experiential learning theory

\begin{abstract}
School Introduction (PLP) is a field practice course to provide comprehensive direct experience to students of the Teacher Training and Education Faculty (FKIP) regarding school understanding and to develop the various competencies of a professional teacher. In the covid-19 pandemic, PLP has been implemented online, so students cannot gain experience directly at the school where PLP is implemented. This practice is less than ideal for the PLP course. This research aimed to analyze the results of reflections on the experiences of students participating in online PLP to determine the mastery of predetermined learning outcomes, positive experiences, obstacles faced by students, attitudes or values that were developed by students, inspirational experiences, and intentions for self-development that arises based on the results of reflection. This research was a qualitative research. The results showed that students could master learning outcomes well and very well, gained various positive experiences and experiences overcoming obstacles that arise due to the pandemic, developed attitudes or values, gained inspirational experiences, and developed intentions for self-development. Thus, the learning cycle in experiential learning theory was experienced by the students participating the online PLP.
\end{abstract}

Keywords: Introduction to School Field, online, experiential learning theory

\title{
Pendahuluan
}

Salah satu tujuan utama perguruan tinggi adalah membekali mahasiswa dengan berbagai keterampilan agar mereka siap memasuki dunia kerja (Santiago, 2009). Untuk mendukung tujuan tersebut, salah satu kegiatan yang dilakukan adalah memberikan pengalaman langsung kepada mahasiswa terkait dengan bidang pekerjaan atau profesi yang akan digelutinya. Di Fakultas Keguruan dan Ilmu Pendidikan (FKIP), sebagai fakultas yang mempersiapkan calon guru, mahasiswa diwajibkan menempuh mata kuliah Pengenalan Lapangan Persekolahan (PLP). PLP merupakan mata kuliah praktik lapangan atau magang (internship) yang dilakukan oleh mahasiswa dengan terjun langsung di sekolah. Mata kuliah ini bertujuan untuk memberikan pengalaman langsung 
secara komprehensif kepada para mahasiswa, sebagai calon guru, tentang dunia persekolahan, serta untuk mengembangkan keterampilan dan kompetensi yang dimiliki seorang guru profesional. Mata kuliah PLP diharapkan dapat membantu mahasiswa mengenal jati diri seorang guru dan semakin memantapkan berbagai kompetensi yang harus dimiliki seorang calon guru (Pedoman PLP PP Daring, 2020:ii).

Dalam Peraturan Menteri Riset, Teknologi, dan Pendidikan Tinggi Republik Indonesia (Permenristekdikti) Nomor 55 Tahun 2017 tentang Standar Pendidikan Guru dijelaskan bahwa Pengenalan Lapangan Persekolahan adalah proses pengamatan/observasi dan pemagangan yang dilakukan mahasiswa Program Sarjana Pendidikan untuk mempelajari aspek pembelajaran dan pengelolaan pendidikan di satuan pendidikan. Dalam Kurikulum FKIP Universitas Sanata Dharma (USD), mata kuliah Pengenalan Lapangan Persekolahan (PLP) terdiri dari 3 bagian, yaitu: 1) PLP Lingkungan Sekolah (PLP LS), 2) PLP Perencanaan Pembelajaran (PLP RP), 3) PLP Pengelolaan Pembelajaran (PLP KP).

PLP merupakan penerapan dari experiential learning (EL) atau pembelajaran berdasarkan pengalaman. Kolb menyatakan bahwa pembelajaran berdasarkan pengalaman adalah proses dimana pengetahuan dihasilkan dari membuat makna sebagai hasil dari pengalaman langsung, atau sederhananya "belajar dari pengalaman" (Zou \& Brown, 2017). Dalam mata kuliah PLP mahasiswa belajar melalui observasi, wawancara, dan interaksi secara langsung dengan kepala sekolah, guru, siswa, tenaga kependidikan, dan semua pihak yang ada di sekolah. Namun dengan adanya pandemi covid-19, pelaksanaan PLP pada periode bulan Juli - Agustus 2020 dilaksanakan secara online atau dalam jaringan (daring). Secara garis besar, konsep pelaksanaan PLP daring yaitu bahwa selama masa pelaksanaan PLP mahasiswa melaksanakan PLP dari lokasi tempat tinggal masing-masing, mahasiswa berinteraksi dengan pihak sekolah melalui alat komunikasi atau media sosial. Proses konsultasi dan pendampingan kepada mahasiswa baik oleh dosen pembimbing maupun guru pamong dilakukan secara daring.

Sebagai mata kuliah praktik lapangan, pelaksanaan PLP secara daring sebenarnya kurang ideal untuk bisa memfaslitasi mahasiswa agar dapat memperoleh pengalaman nyata tentang persekolahan serta mengembangkan kompetensi keguruan. PLP yang didasarkan pada experiential learning mengutamakan pengalaman sebagai dasar untuk menciptakan pengetahuan. Morris T. Keeton and Pamela J. Tate (1978) mendefinisikan experiential learning 
yaitu "Learning in which the learner is directly in touch with the realities being studied. It is contrasted with the learner who only reads about, hears about, talks about, or writes about these realities but never comes into contact with them as part of the learning process" (Kolb, A.Y. \& Kolb, D. A, 2017)

Experiential Learning Theory (ELT) mendefinisikan pembelajaran sebagai "proses dimana pengetahuan diciptakan melalui transformasi pengalaman. Pengetahuan dihasilkan dari kombinasi memperoleh dan mentransformasikan pengalaman” (Kolb \& Kolb, 2005). ELT memberikan model holistik dari proses pembelajaran dan model multi-linear dari perkembangan orang dewasa. Dengan kata lain, ini adalah model pembelajaran orang dewasa inklusif yang bermaksud untuk menjelaskan kompleksitas dan perbedaan antara pelajar dewasa dalam satu kerangka kerja. Fokus dari teori ini adalah pengalaman, yang berfungsi sebagai penggerak utama dalam pembelajaran, karena pengetahuan dikonstruksi melalui proses transformatif refleksi atas pengalaman seseorang (Zou \& Brown, 2017).

Model pembelajaran yang dimunculkan oleh Experiential Learning Theory (ELT) berisi dua cara berbeda untuk memperoleh pengalaman yang terkait satu sama lain (dialektis) dalam satu kontinum, yaitu: pengalaman konkret (concrete experience) dan konseptualisasi abstrak (abstract conceptualization). Selain itu, ada juga dua cara berbeda untuk mengubah pengalaman sehingga pembelajaran tercapai, yaitu: observasi reflektif (reflective observation) dan eksperimen aktif (active experimentation). Ke empat cara ini merupakan siklus pembelajaran empat tahap yang dilalui para siswa dalam proses pembelajaran. Para siswa mulai dengan pengalaman konkret, yang kemudian menuntun mereka untuk mengamati dan merenung tentang pengalamannya. Setelah tahap observasi reflektif ini, peserta didik kemudian mengumpulkan pemikiran mereka untuk menciptakan konsep abstrak tentang apa yang terjadi, yang akan berfungsi sebagai panduan untuk melakukan tindakan di masa mendatang. Dengan panduan ini, para siswa secara aktif membuktikan apa yang telah mereka bangun untuk membentuk pengalaman baru dan memperbarui siklus belajar (Kolb \& Kolb, 2005; Kolb, 1999; Zou \& Brown, 2017).

Menurut Ambrose dan Poklop, pembelajaran berdasarkan pengalaman memberikan praktik dunia nyata yang otentik melalui situasi yang dialami siswa (dan di mana mereka melihat konsekuensi dari tindakan mereka atau orang lain) dan umpan balik nyata dan otentik dari pemberi kerja yang dapat meningkatkan pembelajaran selanjutnya (2015: 56). Dengan pembelajaran seperti ini diharapkan mahasiswa tidak hanya memperoleh ilmu (teori), tetapi juga kerja praktik di lapangan sesuai jurusannya. Demikian pula, K. Hawtrey 
berpendapat bahwa kegiatan pembelajaran berdasarkan pengalaman juga menawarkan kesempatan yang lebih besar bagi mahasiswa untuk membuat hubungan antara studi mereka dan tujuan pribadi mereka, seperti karir atau pengembangan keterampilan pribadi (2010:145).

Magang atau internship merupakan salah satu bentuk dari experiential learning. Davies menyatakan bahwa internship adalah proses pembelajaran berdasarkan pengalaman, di mana siswa memperoleh kesempatan untuk menerapkan teori yang telah dipelajarinya dari sekolah ke situasi kerja yang nyata (Chen \& Chen, 2011). Ada banyak definisi tentang internship. Pauze, Johnson dan Miller memandang bahwa magang mirip dengan kerja lapangan, pengalaman lapangan, praktikum, co-op (cooperative education) atau pembelajaran eksperiensial. Magang adalah pembelajaran berdasarkan pengalaman yang memberi siswa kesempatan untuk mengintegrasikan dan mengkonsolidasikan pemikiran dan tindakan. Renganathan, Abdul Karim dan Chong mendefinisikan magang sebagai kesempatan bagi mahasiswa untuk menggabungkan pengalaman kerja dan pengetahuan mereka ke dalam perkuliahan dengan berada di lingkungan kerja profesional yang diawasi dan direncanakan (Cheong et al., 2013).

Dalam kegiatan magang, mahasiswa akan memiliki kesempatan untuk menemukan minat dan tujuan pekerjaan mereka nantinya di bawah mentor profesional (Chen, Hu, Wang dan Chen, 2011). Pentingnya mengintegrasikan pembelajaran di kelas dengan pengalaman praktis dunia nyata telah diakui sebagai komponen penting dari keterlibatan dan pengembangan siswa dalam pendidikan tinggi. Internship telah diakui sebagai cara yang efektif untuk menjembatani pembelajaran di kelas dengan praktik profesional dan telah disebut sebagai aspek integral dari pengembangan pendidikan dan profesional (Stirling et al., 2017).

Fenomena PLP yang dilaksanakan secara daring menarik untuk dikaji, terkait dengan bagaimana pelaksanaan PLP daring? bagaimana hasil refleksi pengalaman mahasiswa dalam melaksanakan PLP secara daring, terutama pengalaman mahasiswa dalam mengembangkan kompetensi yang dirumuskan dalam capaian pembelajaran? Pengalaman-pengalaman positif apa yang diperoleh mahasiswa, serta kendala apa yang dialami mahasiswa selama melaksanakan PLP daring? Sikap dan nilai-nilai apa yang berkembang dalam diri mahasiswa selama melaksanakan PLP daring? Pengalaman apa yang sungguh menginspirasi mahasiswa dari pelaksanaan PLP secara daring? Serta niat-niat apa yang dibangun mahasiswa berdasarkan hasil refleksinya? 


\section{Metode}

Penelitian ini merupakan penelitian kualitatif. Tujuan penelitian ini adalah menganalisis hasil refleksi pengalaman mahasiswa peserta PLP secara daring untuk mengetahui penguasaan capaian pembelajaran yang telah ditetapkan, pengalaman-pengalaman positif yang diperoleh dan kendala yang dihadapi mahasiswa, sikap atau nilai-nilai yang berkembang dalam diri mahasiswa, serta pengalaman inspiratif dan niat-niat positif yang dibangun berdasarkan hasil refleksi.

Data yang dikumpulkan dalam penelitian ini adalah data primer, yang diperoleh dengan cara menyebarkan kuesioner (angket) kepada para nara sumber atau partisipan, melalui link google form. Nara sumber dalam penelitian ini adalah mahasiswa Program Studi Pendidikan Ekonomi, FKIP, Universitas Sanata Dharma Yogyakarta, yang melaksanakan PLP RP dilanjutkan dengan PLP KP pada periode bulan Juli - Agustus 2020. Nara sumber sebanyak 56 mahasiswa, yang terdiri dari 26 mahasiswa dari Bidang Keahlian Khusus Pendidikan Ekonomi dan 30 mahasiswa dari Bidang Keahlian Khusus Pendidikan Akuntansi.

Kuesioner berisi pertanyaan-pertanyaan untuk mengungkap pelaksanaan PLP secara daring dan hasil refleksi tentang pengalaman mahasiswa selama melaksanakan PLP daring. Kuesioner penelitian disusun untuk mendapatkan data tentang:

1. Identitas mahasiswa peserta PLP RP dan PLP KP

2. Pelaksanaan PLP RP dan PLP KP, yang terdiri dari: tempat pelaksanaan PLP, tempat tinggal selama melaksanakan PLP, dan proses pelaksanaan PLP (proses konsultasi dengan guru pamong, pelaksanaan praktik mengajar, platform yang digunakan dalam praktik mengajar secara daring, media pembelajaran yang dibuat/digunakan mahasiswa dalam praktik mengajar).

3. Refleksi pengalaman mahasiswa, yang meliputi: a) Pengalaman dalam menguasai kompetensi yang dirumuskan dalam capaian pembelajaran (berisi 10 item pertanyaan); b) Pengalaman-pengalaman positif dan kendala yang ditemui selama melaksanakan PLP; c) Sikap-sikap atau nilai-nilai yang berkembang dalam diri mahasiswa selama melaksanakan PLP; d) Pengalaman inspiratif yang diperoleh selama melaksanakan PLP; e) Niatniat yang muncul untuk pengembangan diri sebagai calon guru berdasarkan hasil refleksi 


\section{Hasil Dan Pembahasan}

\section{Deskripsi Pelaksanaan PLP secara Daring}

PLP yang dilakukan pada masa pandemi covid-19 ini bukan hanya berbeda dalam cara pelaksanaannya, dimana biasanya dilakukan secara langsung di sekolah tetapi kemudian dilakukan jarak jauh secara daring. Namun, juga dilakukan penyesuaian dalam capaian pembelajaran dan kegiatan yang harus dilakukan serta output yang dihasilkan. Capaian pembelajaran PLP lebih disederhanakan disesuaikan dengan pelaksanaan secara daring, namun tidak mengurangi esensi dari mata kuliah PLP. Capaian pembelajaran PLP RP dan PLP KP pada saat sebelum pandemi (dilakukan secara luring) dan pada saat pandemi (dilakukan secara daring), adalah sebagai berikut:

\begin{tabular}{|c|c|}
\hline $\begin{array}{c}\text { Capaian Pembelajaran PLP RP } \\
\text { Luring }\end{array}$ & $\begin{array}{c}\text { Capaian Pembelajaran PLP RP } \\
\text { Daring }\end{array}$ \\
\hline $\begin{array}{l}\text { 1. Menelaah kurikulum untuk } \\
\text { menyusun program tahunan (Prota) } \\
\text { dan program semester (Prosem). } \\
\text { 2. Menelaah perangkat pembelajaran } \\
\text { yang digunakan guru untuk } \\
\text { menyusun perangkat pembelajaran } \\
\text { secara mandiri. } \\
\text { 3. Menelaah strategi dan media } \\
\text { pembelajaran yang digunakan guru. } \\
\text { 4. Menelaah sistem evaluasi yang } \\
\text { digunakan guru. } \\
\text { 5. Menyusun perangkat pembelajaran } \\
\text { (Program Tahunan (Prota), } \\
\text { Program Semester (Prosem), } \\
\text { Silabus, RPP dan lampirannya } \\
\text { (Bahan ajar, media, LKS dan } \\
\text { perangkat evaluasi). }\end{array}$ & $\begin{array}{l}\text { 1. Memahami proses penyusunan } \\
\text { program tahunan (Prota) dan } \\
\text { program semester (Prosem). } \\
\text { 2. Menyusun perangkat pembelajaran } \\
\text { daring (Program Tahunan (Prota), } \\
\text { Program Semester (Prosem), } \\
\text { Silabus, RPP dan lampirannya } \\
\text { (bahan ajar, media, LKS dan } \\
\text { perangkat evaluasi). }\end{array}$ \\
\hline
\end{tabular}




\begin{tabular}{|c|c|}
\hline $\begin{array}{c}\text { Capaian Pembelajaran PLP KP } \\
\text { Luring }\end{array}$ & $\begin{array}{c}\text { Capaian Pembelajaran PLP KP } \\
\text { Daring }\end{array}$ \\
\hline $\begin{array}{l}\text { 1. Melaksanakan kegiatan } \\
\text { pembelajaran dengan } \\
\text { menggunakan ragam strategi dan } \\
\text { media pembelajaran. }\end{array}$ & $\begin{array}{l}\text { 1. Menyusun perangkat pembelajaran } \\
\text { daring berupa RPP dan } \\
\text { lampirannya (bahan ajar, media, } \\
\text { LKS dan perangkat evaluasi). }\end{array}$ \\
\hline $\begin{array}{l}\text { 2. Melakukan pengelolaan kelas } \\
\text { dalam pembelajaran }\end{array}$ & $\begin{array}{l}\text { 2. Melaksanakan Pembelajaran secara } \\
\text { daring dengan bimbingan guru, }\end{array}$ \\
\hline $\begin{array}{l}\text { 3. Memanfaatkan TIK dalam } \\
\text { Pembelajaran. }\end{array}$ & $\begin{array}{l}\text { dengan rincian pelaksanaan sebagai } \\
\text { berikut: a) kegiatan pembelajaran }\end{array}$ \\
\hline $\begin{array}{l}\text { 4. Melaksanakan penilaian dan } \\
\text { evaluasi pembelajaran. }\end{array}$ & $\begin{array}{l}\text { memakai ragam strategi dan } \\
\text { media; b) melakukan pengelolaan }\end{array}$ \\
\hline $\begin{array}{l}\text { 5. Melaksanakan tugas-tugas } \\
\text { pendampingan dalam kegiatan } \\
\text { ekstrakurikuler. }\end{array}$ & $\begin{array}{l}\text { kelas; c) memanfaatkan TIK; } \\
\text { d) melaksanakan penilaian dan } \\
\text { evaluasi pembelajaran. }\end{array}$ \\
\hline $\begin{array}{l}\text { 6. Membantu guru dalam } \\
\text { melaksanakan pekerjaan } \\
\text { administrasi guru (perangkat } \\
\text { pembelajaran). }\end{array}$ & $\begin{array}{l}\text { 3. Menemukan persoalan } \\
\text { pembelajaran yang dapat } \\
\text { ditindaklanjuti sebagai kegiatan } \\
\text { penelitian (seperti: Penelitian }\end{array}$ \\
\hline $\begin{array}{l}\text { 7. Menemukan persoalan di kelas } \\
\text { yang dapat ditindaklanjuti sebagai } \\
\text { kegiatan penelitian (Penelitian } \\
\text { Tindakan Kelas atau Research } \mathfrak{G} \\
\text { Development). }\end{array}$ & $\begin{array}{l}\text { Tindakan Kelas atau Research } \mathcal{E} \\
\text { Development). }\end{array}$ \\
\hline
\end{tabular}

Karena PLP dilaksanakan secara daring maka sebagian sekolah tempat pelaksanaan PLP juga berbeda dengan pelaksanaan PLP pada masa sebelum pandemi yang menempatkan semua mahasiswa di sekolah-sekolah mitra yang berlokasi di wilayah DIY dan Klaten. Pelaksanaan PLP pada masa pandemi ini memberikan kesempatan kepada mahasiswa untuk melaksanakan PLP di sekolah yang berlokasi di dekat tempat tinggalnya, khususnya bagi mahasiswa yang sedang pulang ke daerah asalnya (di luar wilayah DIY dan Klaten), dengan mencari/menentukan sendiri sekolah tempat pelaksanaan PLP. Mahasiswa yang sedang berada di luar DIY dan Klaten juga diizinkan untuk melaksanakan PLP di wilayah DIY.

PLP daring dilaksanakan baik di sekolah-sekolah mitra yang berada di wilayah DIY dan Klaten, maupun di luar wilayah DIY dan Klaten. Sebanyak 
48 (85,71\%) mahasiswa melaksanakan PLP di sekolah-sekolah yang berada di wilayah DIY dan Klaten, dan ada 8 (14,29\%) mahasiswa melaksanakan PLP di sekolah-sekolah yang berada di luar DIY dan Klaten. Sekolah di luar DIY dan Klaten yang digunakan untuk melaksanakan PLP berada di berbagai propinsi, antara lain: Bandra Lampung, Jambi, Jawa Barat, Jawa Tengah, Jawa Timur, Kalimantan Barat, Maluku Utara, dan Papua Barat.

Meskipun pelaksanaan PLP ini didesain bahwa semua kegiatan dilaksanakan secara daring, namun pelaksanaannya mengikuti kebijakan sekolah. Di sebagian sekolah, ada kegiatan yang dilakukan secara tatap muka. Konsultasi mahasiswa dengan guru pamong dilaksanakan dengan tatap muka dan daring, dengan proporsi sebagai berikut: 1) mahasiswa yang diberi kesempatan datang ke sekolah untuk berkonsultsi sebanyak 19 (33,93\%) mahasiswa, 2) mahasiswa yang berkonsultasi secara on line dari tempat tinggal sebanyak 14 (25\%) mahasiswa, dan 3) mahasiswa yang berkonsulatasi secara tatap muka dan daring sebanyak $23(41,07 \%)$ mahasiswa.

Pelaksanaan praktik mengajar dalam PLP daring ini juga dilakukan dengan dua cara. Ada sebanyak 35 (62,5\%) mahasiswa yang melaksanakan praktik mengajar secara daring dari tempat tinggal dan 21 (37,5\%) mahasiswa melaksanakan pembelajaran secara daring di sekolah. Dalam melaksanakan praktik pembelajaran daring, mahasiswa menggunakan berbagai platform, diantaranya: Google Classroom, Google Meet, Whatshapp, Zoom, dan e-mail. Sebagian besar mahasiswa menggunakan gabungan minimal dua platform. Platform yang paling banyak digunakan adalah Whatshapp, yaitu oleh 48 (85,71\%) mahasiswa dan Google Classroom oleh 44 (78,57\%) mahasiswa.

Media pembelajaran yang digunakan mahasiswa dalam praktik mengajar secara daring, antara lain: Handout/ringkasan materi dengan format Ms Word atau pdf (oleh 35 mahasiswa), Ms power point bernarasi (oleh 26 mahasiswa), Ms power point tanpa narasi (oleh 34 mahasiswa), video pembelajaran yang diambil dari Youtube maupun membuat sendiri (oleh 36 mahasiswa), multimedia pembelajaran (oleh 5 mahasiswa), serta kuis dengan aplikasi tertentu (oleh 29 mahasiswa). Sebagian besar mahasiswa menggunakan gabungan dari beberapa media.

\section{Refleksi Pengalaman Melaksanakan PLP Daring}

Kegiatan refleksi merupakan bagian dari kegiatan PLP. Mahasiswa merefleksikan semua pengalaman yang dialaminya selama melaksanakan kegiatan PLP. Pada bagian ini diuraikan data penelitian yang berupa hasil 
refleksi mahasiswa mengenai pengalaman melaksanakan PLP RP dan KP secara daring. Hasil refleksi berkaitan dengan: a) sejauh mana mahasiswa mencapai kompetensi yang diharapkan; b) pengalaman positif dan kendala yang dialami; c) Sikap / nilai-nilai yang berkembang dalam diri mahasiswa; d) pengalaman inspiratif yang dialami; serta e) niat-niat yang muncul berdasarkan hasil refleksi.

\section{Refleksi Pengalaman Mengembangkan Kompetensi dalam Capaian Pembelajaran}

Untuk mendapatkan data hasil refleksi mengenai pengalaman dalam mengembangkan kompetensi yang dirumuskan dalam capaian pembelajaran dilakukan dengan memberi 10 pertanyaan kepada para mahasiswa. Pertanyaanpertanyaan ini dimaksudkan untuk mengetahui sejauh mana mahasiswa telah mencapai kompetensi tersebut. Setiap pertamyaan disediakan 5 alternatif jawaban dengan skala Likert. Tabel berikut menyajikan hasil skoring dan interpretasi data capaian pembelajaran mahasiswa dalam mata kulliah PLP RP dan PLP KP, berdasarkan kurva normal.

\begin{tabular}{cccc}
\hline Rentang skor & Kriteria & Frekuensi & Persentase \\
\hline $\mathrm{X}>42$ & Sangat baik & 30 & 53,57 \\
\hline $34<\mathrm{x} \leq 42$ & Baik & 26 & 46,43 \\
\hline $26<\mathrm{x} \leq 34$ & Cukup & 0 & 0 \\
\hline $18<\mathrm{x} \leq 26$ & Kurang baik & 0 & 0 \\
\hline $\mathrm{x} \leq 18$ & Sangat kurang baik & 0 & 0 \\
\hline & & 56 & 100 \\
\hline
\end{tabular}

Data menunjukkan bahwa 30 (53,57\%) mahasiswa termasuk dalam kategori sangat baik dan 26 (46,43\%) mahasiswa termasuk dalam kategori baik, dalam penguasaan capaian pembelajaran mata kuliah PLP RP dan PLP KP.

\section{Refleksi Pengalaman Positif yang Diperoleh dan Kendala yang Dihadapi Selama Melaksanakan PLP Daring}

Ada berbagai pengalaman positif yang diperoleh mahasiswa melalui PLP yang dilaksanakan secara daring. Secara garis besar, pengalaman-pengalaman positif yang dialami mahasiswa dirangkum sebagai berikut:

1. Mahasiswa mendapat pengalaman melaksanakan pembelajaran secara daring (online), serta menggunakan platform atau aplikasi untuk pembelajaran daring. Ini merupakan pengalaman pertama bagi mahasiswa dan juga bagi 
sekolah, sehingga mereka sungguh-sunguh berusaha keras dan memiliki tanggung jawab untuk dapat menyelenggarakan pembelajaran daring dengan sebaik mungkin.

2. Mahasiswa memperoleh pengalaman dalam mengeksplorasi dan membuat berbagai media pembelajaran berbasis teknologi digital, yang menarik, kreatif, dan mudah digunakan, serta strategi pembelajaran daring agar pembelajaran tetap dapat berjalan secara efektif.

3. Mahasiswa mendapatkan pengalaman tentang menyusun perangkat pembelajaran secara daring.

4. Mahasiswa mengalami bagaimana mengelola kelas dalam pembelajaran daring, termasuk memotivasi peserta didik untuk tetap semangat belajar meskipun dalam suasana pandemi. Mahasiswa juga belajar berinteraksi dan mengenal karakteristik peserta didik yang beragam, meskipun secara daring.

5. Mahasiswa mendapat pengetahuan tentang tugas-tugas seorang guru, serta bagaimana cara menjelaskan materi melalui pembelajaran daring, agar peserta didik dapat memahami dengan baik.

6. Mahasiswa belajar tentang bagaimana berinteraksi dan berkomunikasi secara daring baik dengan siswa maupun dengan guru.

Selain mendapatkan banyak pengalaman positif, mahasiswa juga menemui berbagai kendala selama melaksanakan PLP daring. Kendala-kendala yang dihadapi mahasiswa, antara lain:

1. Jaringan internet dan kuota internet. Ini merupakan kendala utama bagi mahasiswa dan juga siswa, mengingat pada awal sampai pertengahan semester belum ada subsidi kuota internet dari pemerintah. Selain itu, tidak semua peserta didik memiliki handphone.

2. Kesulitan memahami dan menghadapi sikap dan perilaku siswa dalam pembelajaran daring. Siswa cenderung pasif, tidak merespon, acuh tak acuh, kurang termotivasi/kurang antusias, tidak atau terlambat dalam mengumpulkan tugas, tidak ada inisiatif, dan merasa jenuh dengan pembelajaran daring. Kesulitan ini dihadapi terutama karena guru dan mahasiswa sebagai praktikan tidak bisa bertatap muka secara langsung dengan siswa, sehingga diperlukan pengelolaan kelas secara lebih intensif.

3. Praktikan mengalami kesulitan dalam memantau proses belajar siswa. Sulit diketahui apakah siswa benar-benar belajar atau tidak, dan materi mana yang belum dipahami siswa. 
4. Kesulitan memahamkan materi kepada siswa ketika materi disampaikan secara daring (misalnya materi dengan banyak hitungan). Kesulitan ini diatasi dengan mengulang penyampaian materi melalui platform atau media lain, misalnya dengan membuat video yang diupload ke Youtube.

5. Kesulitan dalam berkomunikasi secara daring dengan guru pamong mengenai persiapan mengajar, misalnya dalam menentukan strategi dan media pembelajaran, serta dalam mencari solusi ketika menghadapi masalah.

6. Kesulitan dalam memakai platform atau aplikasi (Google classroom, Google meet, zoom) yang akan digunakan dalam pembelajaran, serta membuat media pembelajaran (power point) yang menarik dan kreatif.

\section{Refleksi Mengenai Sikap atau Nilai-nilai yang Berkembang selama Melaksanakan PLP Daring}

Selama pelaksanaan PLP daring ada sikap-sikap atau nilai-nilai yang dikembangkan dalam diri mahasiswa. Sikap dan nilai tersebut penting dimiliki oleh mahasiswa sebagai seorang calon guru. Berdasarkan data yang diperoleh dalam penelitan ini, beberapa nilai dan sikap yang berkembang dalam diri mahasiswa, antara lain: tanggung jawab, disiplin, sabar, toleransi, saling menghargai dan menghormat, saling membantu, sopan santun dalam pembelajaran maupun berkomunikasi secara daring, terbuka, ketulusan dalam mengajar, jujur, tekun, mau menerima kritik, tegas, kreatif, tegas, kepemimpinan, percaya diri, mandiri, rajin, teliti, kerja Keras, kedewasan, menghargai waktu, tidak menunda pekerjaan, kerapian, lebih peka, peduli, ramah, mau memperbaiki diri, taat, semangat, mengajar dengan sepenuh hati, memiliki hati untuk mendidik, telaten, inovatif, tepat waktu.

\section{Refleksi Pengalaman Inspiratif yang Diperoleh Selama Melaksanakan PLP secara Daring}

Selama melaksanakan PLP secara daring, mahasiswa mendapatkan berbagai pengalaman yang memberi inspirasi untuk melakukan tindakan tertentu di masa yang akan datang, khususnya jika mereka menjadi seorang guru. Pengalaman inspiratif yang banyak dialami mahasiswa selama melaksanakan PLP, berkaitan dengan proses pembelajaran yang terjadi di masa pandemi covid-19 ini. Praktik pembelajaran secara daring merupakan pengalaman pertama dan sekaligus juga merupakan pengalaman yang tidak terbayangkan sebelumnya oleh mahasiswa. Sebagian mahasiswa merasakan bahwa menjadi 
guru tidaklah mudah terutama di masa pandemi. Namun, mahasiswa yang lain justru memandang bahwa pembelajaran daring merupakan pengalaman positif yang menginspirasi. Permasalahan yang muncul terkait dengan motivasi belajar peserta didik selama pembelajaran daring serta beragamnya karakter peserta didik juga memperkaya pengalaman mahasiswa tentang bagaimana mengatasi persoalan tersebut.

Berikut beberapa pengalaman inspiratif yang diungkapkan oleh mahasiswa peserta PLP RP dan KP daring:

"Pengalaman yang sungguh ispiratif bagi saya yaitu ketika saya berusaha membuat siswa aktif dalam pembelajaraan daring. Ternyata hal ini tidak muda apalagi proses pembelajaran daring saya sangat kesulita memantau perkembangan siswa tetapi hal itu saya bisa lewati dan ternyata menjadi seorang guru itu tidaklah mudah tetapi hal ini tidak jadi masalah melainkan hal ini menjadi pengalaman yang sangat berarti bagi saya kedepannya jika saya menjadi seorang guru."

"Pengalaman inspiratif bagi saya adalah di saat pandemi seperti saat ini, dengan keterbatasan yang ada namun guru-guru di sekolah tempat saya melaksanakan PLP tetap semangat dan berusaha semaksimal mungkin untuk melakukan proses pembeljaran dengan baik"

"Siswa yang tidak aktif dalam pembelajaran membuat saya menjadi terinspirasi suatu saat ketika saya menjadi seorang guru, saya harus bisa meningkatkan motivasi siswa untuk mau belajar."

"Inspiratif ketika saya praktek langsung sebagai guru, di samping menyenangkan belajar bersama siswa, saya juga banyak belajar untuk bisa memahami kondisi mereka di tengah masa sulit, dan bisa menjadi guru sekaligus teman daring bagi mereka. Sehingga hal ini memantapkan diri saya untuk menjadi seorang guru."

"Awalnya saya belum ada minat menjadi seorang guru, namun setelah mengikuti kegiatan PLP-RP-KP hati saya mulai tergerak untuk menjadi seorang pendidik di masa depan."

"Pengalaman yang membuat saya menjadi sadar untuk semangat lagi. setelah melihat siswa yang sangat semangat di dalam kelas, membuat saya sadar kalau saya juga harus seperti dia lebih semangat dan bersyukur dengan apa yang saya punya sekarang ini"

"Mengajar online itu tidak mudah, salut dengan guru-guru yang berusaha mempelajari TIK demi murid-muridnya"

"Guru yang selalu memberikan perhatian kepada siswanya. Guru pamong 
saya pernah bercerita bahwa beberapa siswa tidak mengerjakan soal atau kuis tepat waktu dikarenakan membantu orang tua nya berkerja, lalu guru pamong saya memberikan waktu yang cukup banyak untuk mengerjakan soal atau kuis tersebut. Apabila ada siswa yang tidak hadir selalu ditanyakan kenapa. Menurut saya hal tersebut sangat membantu siswa yang mungkin mengalami kendala saat melaksanakan kegiatan pembelajaran secara daring. Membuat saya menjadi lebih peduli apabila besok saya menjadi guru dan masih dalam keadaan seperti ini."

"Guru bukan hanya mengajar, melainkan merangkap sekaligus sebagai konsultan ketika siswa mengalami kesulitan dalam pembelajaran daring."

"Memiliki guru pamong yang sudah lebih dari 30 tahun mengajar dan mengabdi sebagai guru dengan sangat sabar."

"Pengalaman yang sungguh luar biasa dan inspiratif bisa merasakan mengajar siswa, ternyata menjadi seorang pendidik bukanlah hal yang mudah, ada banyak hal yang harus kita persiapkan dengan baik, sehingga dapat menjadikan pengalaman untuk belajar mengendalikan emosi (sabar), memiliki tanggung jawab jawab, menghargai orang lain, tidak pilih kasih, dan masih banyak lainnya."

Pengalaman inspiratif yang lain secara umum berkaitan dengan: 1) perlunya kesabaran pendidik dalam menghadapi karakteristik dan permasalahan belajar peserta didik yang beragam, 2) semangat untuk tetap melaksanakan pembelajaran meskipun ada banyak keterbatasan, 3) perlunya menyesuaikan diri dengan perkembangan teknologi, 4) perlunya sikap kreatif dan inovatif dalam membuat media dan model pembelajaran yang efektif; 5) keramahan dari para guru, 6) relasi yang baik dengan siswa; 7) pengalaman mengelola kelas dan menyampaikan materi kepada siswa, 8) pengalaman membuat administrasi guru dan perangkat evaluasi belajar siswa.

\section{Niat-niat yang Dibangun Mahasiswa Berdasarkan Hasil Refleksi}

Setelah merefleksikan pengalaman selama melaksanakan PLP secara daring, kemudian mahasiswa diberi kesempatan untuk membangun niatniat pengembangan diri sebagai calon guru, berdasarkan hasil refleksi pengalamannya. Dari berbagai niat yang disampaikan, secara garis besar dapat dikelompokkan menjadi tiga, yaitu:

1. Niat untuk belajar dan memperdalam berbagai hal terkait kegiatan pembelajaran, sehingga nantinya dapat melaksanakan pembelajaran dengan lebih baik. Misalnya: mempelajari berbagai aplikasi untuk pembelajaran 
daring, mengasah kemampuan dalam bidang teknologi, mengelola kelas, membuat dan menggunakan media yang menarik, mempelajari berbagai strategi / model pembelajaran yang cocok dengan karakter peserta didik, mengikuti perkembangan ekonomi, memahami karakter siswa yang beragam, memperluas pengetahuan, selalu memperdalam ilmunya, menyiapkan materi pelajaran dengan baik.

2. Niat untuk menjadi seorang guru. Sebagian mahasiswa bahkan baru berniat menjadi guru setelah melaksanakan PLP RP dan PLP KP ini. Profil guru yang diinginkan adalah guru yang profesional, memiliki kecakapan yang baik dan dapat menjadi panutan/contoh bagi siswa, guru yang luwes, bertanggung jawab, jujur, peduli, memiliki relasi yang baik dengan siswa, kreatif, inovatif, percaya diri, dapat menjadi teman belajar bagi siswa, dapat mendidik dengan hati, terbuka untuk membantu kesulitan siswa, menjadi pendengar yang baik, tidak membeda- bedakan siswa, dan bisa mendidiksiswa agar memiliki moral yang baik.

3. Niat untuk memperbaiki dan mengembangkan diri. Misalnya, niat untuk selalu giat belajar, disiplin, jujur, menjadi lebih sabar, lebih percaya diri saat berbicara di depan banyak orang (meningkatkan kemampuan public speaking), menjadi profesional, bertanggung jawab, tetap semangat dalam keadaan apapun, banyak membaca dan belajar, serta mengelola diri dan waktu.

\section{Pembahasan}

Dari hasil refleksi pengalaman mahasiswa dalam mengembangkan kompetensi keguruan pada pelaksanaan PLP RP dan KP secara daring menunjukkan bahwa para mahasiswa dapat menguasai kompetensi yang harus mereka capai dalam mata kuliah PLP RP dan PLP KP. Ini terlihat dari skor hasil refleksi yang diperoleh melalui kuesioner berada pada kategori baik dan sangat baik. Ini dapat dimaknai bahwa meskipun PLP dilaksanakan secara daring, namun proses pembelajaran tetap dapat berlangsung dengan baik. Kegiatan refleksi yang terintegrasi dalam mata kuliah PLP, membantu mahasiswa dalam memaknai setiap pengalaman yang dialaminya, sehingga dapat membentuk konsep-konsep abstrak (abstract conceptualization) baru. Dalam hal ini refleksi merupakan proses yang penting dalam mendukung pembelajaran melalui pengalaman. Menurut Wurdinger \& Allison (2017: 16-17), proses belajar terjadi ketika seseorang menjalani pengalaman, merefleksikannya, dan membentuk 
konsep yang dapat diterapkan pada pengalaman masa depan. Berdasarkan teori Kolb, merefleksikan pengalaman memungkinkan seseorang untuk membuat hubungan antara pengalaman dan konsep teoritis yang kemudian dapat membantu memperbaiki dan meningkatkan pengalaman masa depan yang serupa. Menjalani suatu pengalaman tanpa refleksi meninggalkan pembelajaran yang terjadi.

Aktivitas refleksi bukan saja dibutuhkan dalam proses pembelajaran mahasiswa calon guru melalui program magang, tetapi juga tetap dibutuhkan dalam pengembangan profesionalitas guru. Pengembangan pribadi, sebagai bagian dari pengembangan profesional, sering dilakukan melalui aktivitas reflektif. Guru sebagai peserta aktif dalam pembelajaran didorong untuk melakukan pengembangan profesinya melalui praktik reflektif. Fokus pada refleksi dan partisipasi aktif dalam pengembangan profesional ini secara teoritis didukung oleh experiential learning theory (Girvan, Conneely, \& Tangney, 2016). Refleksi atas tindakan sebagai alat utama untuk pengembangan profesional telah digunakan baik sebagai alat untuk pengarahan diri sendiri (self-direction) (Minot, 2010), maupun untuk mengembangkan pemahaman dan praktik melalui berbagi pengalaman (Girvan, Conneely, \&Tangney, 2016). Dalam pengembangan profesionalisme guru, penerapan experiential learning sudah banyak dilakukan. Fokusnya pada pengalaman guru dalam mengembangkan praktik pembelajaran di kelas, guru bereksperimen, merefleksikan, dan mengadaptasi teori, praktik, dan konten baru yang sesuai dengan konteks mereka.

Pengalaman-pengalaman positif yang diperoleh mahasiswa, dan kendalakendala yang dihadapinya, serta nilai-nilai dan sikap yang berkembang dalam diri mahasiswa selama pelaksanaan PLP secara daring, membantu mahasiswa dalam mengembangkan kompetensinya sebagai calon guru secara komprehensif. Semua pengalaman yang dialami dan direfleksikan mahasiswa menjadi pengetahuan baru yang dapat bermanfaat dalam proses pembelajaran selanjutnya maupun ketika mereka menjadi guru. Seperti diungkapkan oleh Chen at al. (2011) bahwa kegiatan magang membantu membiasakan peserta magang dengan keterampilan praktis, meningkatkan hubungan sosial, memotivasi pembelajaran di masa depan, dan mengembangkan kepribadian yang dapat diterima secara sosial.

Berbagai kendala yang secara nyata dihadapi mahasiswa dengan adanya pandemi covid-19, secara tidak langsung juga telah melatih mahasiswa untuk memecahkan permasalahan baru yang belum pernah dialaminya. Pengalaman 
semacam inilah yang justru berperan dalam memperkaya pengetahuan dan keterampilan mahasiswa. Ini sesuai dengan yang disampaikan oleh Wurdinger \& Carlson, bahwa experiential learning juga mengutamakan penerapan prinsip-prinsip pembelajaran langsung, menggunakan proses pemecahan masalah, mengatasi permasalahan yang nyata, mendorong interaksi sosial dan interaksi dengan konten, serta menggunakan beberapa mata pelajaran secara interdisipliner (Wurdinger \& Allison, 2017: 17).

Mahasiswa juga menemukan banyak pengalaman inspiratif selama melaksanakan PLP RP dan KP secara daring. Pengalaman tersebut tentu merupakan pengalaman bermakna dan berkesan bagi mahasiswa, yang dapat menstimulasi munculnya niat-niat positif yang bermanfaat bagi pengembangan pribadinya sebagai calon guru. Dengan demikian, Experiential Learning Theory dari Kolb, memiliki potensi yang besar dalam lingkungan pendidikan dan kemampuan untuk meningkatkan proses pendidikan guru (Clark, Threeton, \& Ewing, 2010).

\section{Simpulan}

Mata kuliah PLP sebagai salah satu bentuk penerapan experiential learning dimaksudkan untuk memberikan pengalaman langsung kepada mahasiswa calon guru agar memahami dunia persekolahan dan mengembangkan kompetensinya secara menyeluruh sehingga memiliki bekal yang memadai ketika akan terjun ke dunia pendidikan sebagai seorang guru. Dalam masa pandemi covid-19, PLP dilaksanakan secara daring, sehingga sebagian besar mahasiswa tidak dapat memperoleh pengalaman langsung di sekolah tempat pelaksanaan PLP. Interaksi mahasiswa praktikan dengan guru pamong dan siswa dilakukan secara jarak jauh. Praktik ini menjadi kurang ideal untuk mata kuliah PLP yang merupakan mata kuliah praktik lapangan.

Data yang diperoleh dari para mahasiswa, berupa hasil refleksi pengalaman selama melaksanakan PLP, menunjukkan bahwa meskipun PLP dilaksanakan secara daring namun para mahsiswa dapat memperoleh keterampilan dan kompetensi yang diharapkan. Setelah melaksanakan PLP, mahasiswa dapat menguasai dengan baik kompetensi seperti yang telah dirumuskan dalam capaian pembelajaran. Beragam pengalaman positif, pengalaman mengatasi kendala yang muncul akibat pandemi, berkembangnya sikap dan nilai positif juga melengkapi dan memperkaya pengalaman belajar mahasiswa di mata kuliah PLP RP dan PLP KP. Pengalaman inspiratif juga 
dialami oleh para mahasiswa, sehingga memunculkan niat-niat positif untuk pengembangan diri yang bermanfaat untuk saat ini maupun ketika menjalani profesi sebagai guru. Dengan demikian siklus belajar dalam experiential learning theory yaitu dari concrete experience, reflective observation, abstract conceptualisation, dan active experimentation dialami oleh para mahasiswa yang melaksanakan PLP $\mathrm{RP}$ dan KP secara daring.

\section{Daftar Pustaka}

Ambrose, S.A., Poklop, L. (2015). Do students really learn from experience?. Change: The magazine of higher learning. February 2015. DOI: 10.1080/00091383.2015.996098.

Chen, C-T., Chen, C-F. (2011). The influence of internship experiences on the behavioral intentions of college students in Taiwan. The Asia-Pacific Education Researcher, Vol. 20, No. 1, pp. 73-92.

Chen, A-T., Hu, J-L., Wang, C-C., Chen, C-F. (2011). A study of the effects of internship experiences on the behavioural intentions of college students majoring in leisure management in Taiwan. Journal of Hospitality, Leisure, Sport and Tourism Education. Vol. 10, No. 2. DOI:10.3794/johlste.102.294

Cheong, A.L.H., Yahya, N., Shen, Q.L., Yen, A.Y. (2013). Internship Experience: An in-depth interview among interns at a business school of a malaysian private higher learning institution. Procedia - Social and Behavioral Sciences 123 ( 2014$) 333-343$

Clark, R. W., Threeton, M. D., \& Ewing, J. C. (2010). The potential of experiential learning models and practices in career and technical education and career and technical teacher education. Journal of Career and Technical Education, Vol. 25, No. 2: pp. 46-62

Girvan, C., Conneely, C., Tangney, B. (2016). Extending experiential learning in teacher professional development. Teaching and Teacher Education 58, p. 129-139. http://dx.doi.org/10.1016/j.tate.2016.04.009

Hawtrey, K. (2010). Using experiential learning techniques. The Journal of Economic Education, 2010, 38:143-152.

Kolb, A.Y. \& Kolb, D. A. (2017). Experiential learning theory as a guide for experiential educators in higher education. A Journal for Engaged Educators, Vol. 1, No. 1, pp. 7-44

Kolb, D.A., Boyatzis, R.E., Mainemelis, C., (1999). Experiential learning theory: 
Analisis pelaksanaan mata kuliah pengenalan lapangan persekolahan (plp) ... (Benedecta Indah Nugraheni)

Previous research and new directions.

Kolb, A.Y., \& Kolb, D.A., (2005). Learning styles and learning spaces: Enhancing experiential learning in higher education. Academy of Management Learning 8 Education. Vol. 4, No. 2, pp. 193-212

Minott, M. A. (2010). Reflflective teaching as self-directed professional development: Building practical or work-related knowledge. Professional Development in Education, 36(1e2), 325e338. http://www.tandfonline. com/loi/rjie20

Permenristekdikti, Nomor 55 Tahun 2017 Tentang Standar Pendidikan Guru.

Santiago, A. (2009). Impact of sandwich course design on first job experience. The Asia-Pacific Education Researcher 18:2, pp. 205-217.

Stirling, A., Kerr, G., MacPherson, E., Banwell, J., Bandealy, A., Battaglia, A. (2017). Do postsecondary internships address the four learning modes of experiential learning theory? An exploration through document analysis. Canadian Journal of Higher Education. Volume 47, No. 1, pp. 27 - 48

Wurdinger, S., Allison, P. (2017). Faculty perceptions and use of experiential learning in higher education. Journal of e-Learning and Knowledge Society. Vol. 13, n.1, pp. 15-26. ISSN: 1826-6223, e-ISSN:1971-8829.

Zhou, M., \& Brown, D. (2017). Educational Learning Theories: 2nd Edition. In Education Open Textbooks. https://oer.galileo.usg.edu/educationtextbooks/1

Pedoman Pelaksanaan Program Pengenalan Lapangan Persekolahan (PLP) Pengelolaan Pembelajaran. Edisi Daring. FKIP Universitas Sanata Dharma. 
Humanika, Kajian IImiah Mata Kuliah Umum, Vol. 21. No. 2. (2021), 173-192 